\title{
Occurrence of Clostridium chauvoei in Sheep and Goats in Kashmir Valley
}

\author{
Q. Beigh*, I. Hussain, S.A. Wani, S. Rasool, Q. Nyrah, Z.A. Kashoo, \\ N. Nazir, A.H. Wani and S. Qureshi
}

\begin{abstract}
Bacteriology Laboratory, Division of Veterinary Microbiology and Immunology, Sher-e-Kashmir University of Agricultural Sciences and Technology of Kashmir,

Shuhama (Alusteng), Srinagar 190006, India

*Corresponding author
\end{abstract}

K e y w o r d s
$\begin{aligned} & \text { Clostridium chauvoei, } \\ & \text { Faeces, Goat, Sheep } \\ & \text { and PCR. }\end{aligned}$
Article Info
$\begin{aligned} & \text { Accepted: } \\ & \text { 24 September } 2017 \\ & \text { Available Online: } \\ & \text { 10 November } 2017\end{aligned}$

A B S T R A C T
The current study reports the occurrence of Clostridium chauvoei in sheep and goats in Kashmir valley. A total of 412 faecal samples were collected from different organized and unorganized sheep and goat farms of the Kashmir valley. The samples consisted of 212 samples from sheep (adult-70, lamb-42) and goats (adult-80, kid-20) without diarrhoea (healthy) and (adult-40, lamb-60) and goats (adult-70, kid-30) with diarrhoea, were enriched in RCM broth before final isolation on blood agar plates. Suspected haemolytic colonies were purified and were identified tentatively as C. chauvoei based on Gram's staining and morphological characteristics, colony characteristic and biochemical tests. They were finally identified by $16 \mathrm{~S}$ rRNA gene specific PCR. Out of the 70 adult sheep and 42 lamb samples without diarrhoea, C. chauvoei was obtained from $8(11.42 \%)$ and $10(23.8 \%)$ samples, respectively. Similarly, 5(12.5\%) and $15(25 \%)$ samples from 40 adult sheep and 60 lambs with diarrhoea, respectively yielded $C$ chauvoei. Likewise, 1(1.25\%) and $2(10 \%)$ isolates were recovered from 80and 20 healthy adult goat and kid samples, respectively. The diarrhoeic samples yielded $2(12.5 \%)$ and $3(10 \%)$ isolates from adult goats and kids, respectively. The overall prevalence of $C$. chauvoei in sheep and goat was found to be $11.16 \%$. Lambs and kids were found to harbour more Clostridium chauvoei than the adult animals of the corresponding species.

\section{Introduction}

The Clostridium is one of the bacterial genera that comprise the group of anaerobic bacteria of considerable medical and economic importance. Among different Clostridium spp, Clostridium chauvoei is a highly pathogenic bacterium that causes blackleg or black quarter in cattle, sheep and many other ruminants causing economic losses in livestock (Abreu and Uzal, 1984; Hatheway, 1990). It is the second most important bacterial disease in India next only to haemorrhagic septicaemia in causing death among bovids (Dangi et al., 2014). Although, C. chauvoei is mainly considered to be specific to ruminants, rare fatal cases of fulminant human gas gangrene and neutropenic enterocolitis caused by $C$. chauvoei have been reported and it is assumed that prevalence of $C$. chauvoei causing disease in humans may be higher than currently diagnosed (Nagano et al., 2008; Weatherhead and Tweardy, 2012). 
C. chauvoei is Gram-positive rod, histotoxic, motile and endospore forming bacterium that requires strict anaerobic conditions and media rich in cysteine and water soluble vitamins for growth (Hirsh et al., 2004). The organism ferment glucose, fructose, lactose, maltose, and mannose. It produces acetic and butyric acids as metabolic end products. C. chauvoei has been detected in manure which also represents a source of infection (Bagge et al., 2009). Blackleg has been recorded in young stock between ages of 6 to 24 months of age. While presumptive diagnosis of blackleg and malignant edema depends on clinical and pathological findings, the confirmation of disease is typically found by isolating and identifying the organism, such as toxin production and immunological methods. However, these diagnostic methods are time consuming and laborious. In addition, immunological methods may yield equivocal results because $C$. chauvoe $i$ and $C$. septicum have various antigens in common. Nucleic acid amplification of a specific target region of the bacterial genome by the polymerase chain reaction has been widely used for detection and diagnosis purposes. The ability of PCR to amplify DNA specifically from low numbers of bacteria, as well as its simplicity, rapidity and reproducibility, offers advantages over conventional methods for identification, and has been actually used to identify many Clostridium species, including $C$. chauvoei in pure cultures and in clinical samples.

Although, the disease occurs in young animals, the epidemiology in particular occurrence of the organisms in healthy animals and the spreading of this pathogen from the digestive tract to muscle tissue where lesions are most abundant and the organism is found at high amount assumingly due to replication, is largely unknown. In this paper we describe isolation of $C$. chauvoei from faecal samples of clinically healthy and diarrhoeic sheep and goats and their confirmation by PCR in Kashmir.

\section{Materials and Methods}

A total of 412 feacal samples were collected from different organized and unorganized sheep and goat farms of Kashmir valley during the course of study. The samples consisted of 212 samples from sheep (adult70, lamb-42) and 200 goats (adult-80, kid-20) without diarrhoea (healthy) and 100 sheep (adult-40, lamb-60) and goats (adult-70, kid30) with diarrhoea The samples were collected with sterile swabs and carried on ice to the laboratory, where they were processed immediately in the Division of Veterinary Microbiology \& Immunology, FVSc \& AH, Suhama, Alusteng, for the isolation and identification of C.chauvoei.

\section{Isolation and identification of $C$. chauvoei}

The $C$. chauvoei was isolated as per the method described by Miyashiroet al., (2007) with some modifications. Feacal samples were inoculated in Difco ${ }^{\mathrm{TM}}$ Cooked meat medium (Becton, Dickinson and Company, Sparks, MD, USA) and incubated anaerobically in 3.5 litre anaerobic jar (Oxoid Limited, Thermo Fisher Scientific Inc., UK) with GasPak $^{\mathrm{TM}}$ Anaerobe Container System (Becton, Dickinson and Company, Sparks, MD, USA) for 4- 5days. Then one $\mathrm{ml}$ of broth was treated with equal quantity of absolute alcohol for $30 \mathrm{~min}$ to one hour before plating on 5\% Sheep blood agar plates. The plates were incubated anaerobically for 3-4 days at $37 \mathrm{C}^{0}$. After incubation suspected haemolytic colonies were sub-cultured on Bacto ${ }^{\mathrm{TM}} 3.5 \%$ Brain Heart Infusion agar plates (Becton, Dickinson and Company, Sparks, MD, France) until they were free from contaminating bacteria. The typical flat and whitish grey coloured colonies suggestive of 
C. chauvoei were identified tentatively based on Gram's staining, morphological characteristics and biochemical tests, as per Jousimies-Somer et al., (2003).

\section{Extraction of bacterial DNA}

The template DNA was prepared by boiling and snap chill method. Briefly, Purified individual colony from BHI agar plate (HiMedia, India) were suspended in $1.5 \mathrm{ml}$ micro centrifuge tubes containing $100 \mu \mathrm{l}$ sterile double distilled water. The tubes were boiled for $10 \mathrm{~min}$ and then cooled on ice for $10 \mathrm{~min}$ and centrifuged at $11000 \times \mathrm{g}$ for $10 \mathrm{~min}$ in a refrigerated centrifuge (Cooling Centrifuge, Eppendorf 5418R, Hamburg, Germany). Three microlitres $(\mu \mathrm{l})$ of the supernatant was used as the template for PCR.

\section{Identification of Clostridium chauvoei by species specific PCR}

The bacterial isolates identified by cultural and biochemical methods as C. chauvoei were genetically confirmed by PCR targeting 16SrRNA gene of $C$. chauvoei as described by Uzal et al.,(2003). Primers pairs namely forward-CC16S-L-5'GTCGAGCGAGGAGA GTTC3' and reverse- CC193-R-5'CGGATTG CTCCTTTAATTAC3' were used in the present study. All the PCR assays in this study were performed in $25 \mu \mathrm{l}$ reaction volume in a thermal cycler (Master Cycler Gradient, Eppendorf AG, Hamburg, Germany). The reaction consisted of $3.0 \mu \mathrm{l}$ template DNA, $2.5 \mu 1$ of $10 \mathrm{X}$ buffer, $0.2 \mu 1$ of $25 \mathrm{mM}$ dNTP mix, $0.3 \mu 1$ (1 unit) Taq DNA polymerase, $1 \mu 1$ of each forward and reverse primers $(25 \mu \mathrm{M})$ and nuclease free water. The $\mathrm{MgCl}_{2}$ was adjusted used at $2.0 \mathrm{mM}$ concentration. The PCR conditions consisted of initial denaturation for $5 \mathrm{~min}$ at $94^{\circ} \stackrel{\circ}{\mathrm{C}}$ followed by 32 cycles of denaturation for 1 min at $94^{\circ} \dot{\mathrm{C}}$, annealing for $1 \mathrm{~min}$ at $50^{\circ} \stackrel{\circ}{\mathrm{C}}$ and extension for $2 \mathrm{~min}$ at $72{ }^{\circ} \mathrm{C}$ followed by one cycle of 1 min at $50^{\circ} \mathrm{C}$ and 5 min at $72^{\circ} \stackrel{\circ}{\mathrm{C}}$. Chauvoei isolates obtained from Dr. P. Borah, Department of Animal Biotechnology, College of Veterinary Science, AAU, Khanapara, Guwahati-22 was used as positive control, while sterile distilled water served as negative control in the PCR assay. The primers were procured from GCC Biotech, Kolkata, India.

After amplification, the PCR products were mixed with 6x loading dye and loaded in separate wells on the submerged agarose gel $(3 \%, \mathrm{w} / \mathrm{v})$. Standard molecular weight marker (Fermentas Life Sciences) was also loaded in one well. The gel was visualized under ultraviolet illumination and photographed with the help of a gel documentation system (Ultra Cam Digital Imaging, Ultra. Lum. Inc., Claremont, CA).

\section{Results and Discussion}

In the present study a total of 412 faecal samples were screened for $C$. chauvoei in sheep and goat populations from different regions of Kashmir valley.Some of the tubes containing the cooked meat medium, where enrichment of the faecal samples were done showed black discolouration of the meat pieces.Furthersub-culturing of the sampleson 5\% sheep blood agar showed haemolysis around the colonies (Fig. 1). The isolates produced small slightly raised whitish grey coloured colonies on BHI agar (Fig. 2). On Gram's staining the isolates appeared Grampositive rods with sub terminal spores suggestive of $C$. chauvoei. All the isolates were catalase positive and fermented glucose, maltose, sucrose and lactose. The isolates were negative for indole, methyl red, oxidase, lipase and lecithinase test. All the isolates identified as $C$. chauvoei by conventional method, were found to amplify a159 bp product corresponding to16S rRNA gene of C. chauvoei by PCR (Fig. 3). Out of the 70 
healthy adult sheep and 42 lamb samples, $C$. chauvoei was obtained from $8(11.42 \%)$ and $10(23.8 \%)$ samples, respectively (Table 1). Similarly, 5(12.5\%) and $15(25 \%)$ samples from 42 adult sheep and 60 lambs with diarrhoea, respectively yielded $C$. chauvoei. Likewise, $1(1.25 \%)$ and $2(10 \%)$ isolates were recovered from 80 healthy adult goats and 20 healthy kid samples, respectively. The diarrhoeic samples yielded $2(2.85 \%)$ and $3(10 \%)$ isolates from adult goats and kids, respectively Lambs and kids were found to harbour more Clostridium chauvoei than the adult animals of the corresponding species.

C. chauvoei causes black quarter which is considered one of the most devastating diseases of livestock with significant economic impact around the globe (Quinn et al., 2004; Radostitis et al., 2006). The $C$. chauvoei is a strict anaerobe microorganism and it survives in the environment and in host muscles for decades. The isolation of $C$. chauvoei is very difficult, since it requires strict anaerobic conditions, and clinical specimens are often contaminated with other anaerobic bacteria including other Clostridia in soil, which grow faster than $C$. chauvoei in a culture medium. Infections due to clostridia microorganisms cause considerable losses in the production, treatment generally is impracticable. Control and prevention must comprise adequate measures of handling and systematic vaccination of the flock. Further, the epidemiology of the disease is largely unknown. On the other hand, there is very little information on the isolation of the organism from sources other than clinical cases (Bagge et al., 2009).

In the present study, we investigated the occurrence of $C$. chauvoei in sheep and goats of Kashmir valley. Robertson cooked meat medium was used as enrichment medium for the samples, it lowers redox potential level which provides favorable anaerobic conditions for growth of $C$. chauvoei. Further the isolates produced haemolysis on 5\% sheep blood agar plate, the characteristics features of C. chauvoei described by Quinn et al., (2004). Isolates when streaked on 3.5\% BHI agar plates found to produce small, irregular, whitish grey coloured colonies. These findings correlate with the previous study reported by Idrees et al., (2014).

Table.1 Details of the samples and isolates of $C$. chauvoei from sheep and goats

\begin{tabular}{|l|l|l|l|c|c|}
\hline Species & Age group & $\begin{array}{l}\text { Nature of } \\
\text { Sample }\end{array}$ & $\begin{array}{l}\text { No of } \\
\text { Sample } \\
\text { examined }\end{array}$ & $\begin{array}{l}\text { No of positive } \\
\text { sample/isolates } \\
\text { recovered }\end{array}$ & $\begin{array}{l}\text { Per cent } \\
\text { positive }\end{array}$ \\
\hline \multirow{3}{*}{ Sheep } & \multirow{2}{*}{ Adult } & Healthy & 70 & 8 & 11.42 \\
\cline { 2 - 6 } & Diarrhoeic & 40 & 5 & 12.5 \\
\cline { 2 - 6 } & \multirow{2}{*}{ lamb } & Healthy & 42 & 10 & 23.8 \\
\cline { 2 - 6 } & Adult & Diarrhoeic & 60 & 15 & 25 \\
\hline \multirow{3}{*}{ Goat } & Healthy & 80 & 1 & 1.25 \\
\cline { 2 - 6 } & Kid & Diarrhoeic & 70 & 2 & 2.85 \\
\cline { 2 - 6 } & Healthy & 20 & 2 & 10 \\
\cline { 2 - 6 } & Diarrhoeic & 30 & 4 & 11.16 \\
\hline
\end{tabular}


Fig.1 Hemolysis produced by Clostridium chauvoei on sheep blood agar

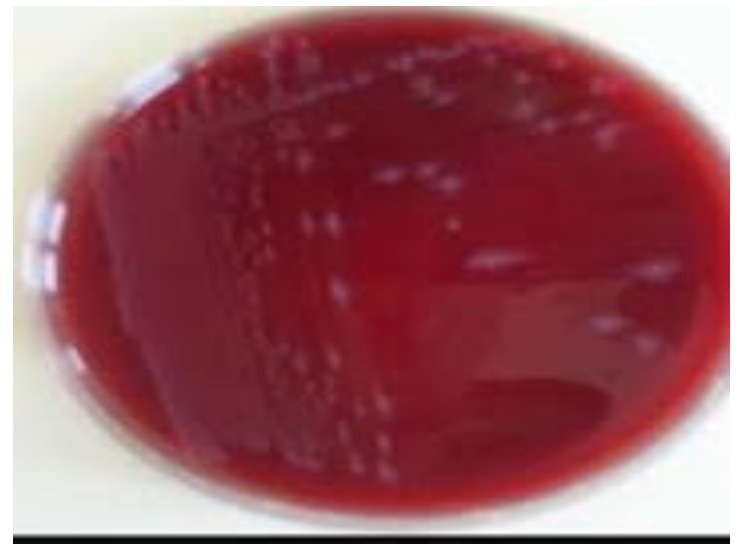

Fig.2 Small irregular, whitish grey colored colonies of Clostridium chauvoei on BHI agar plate

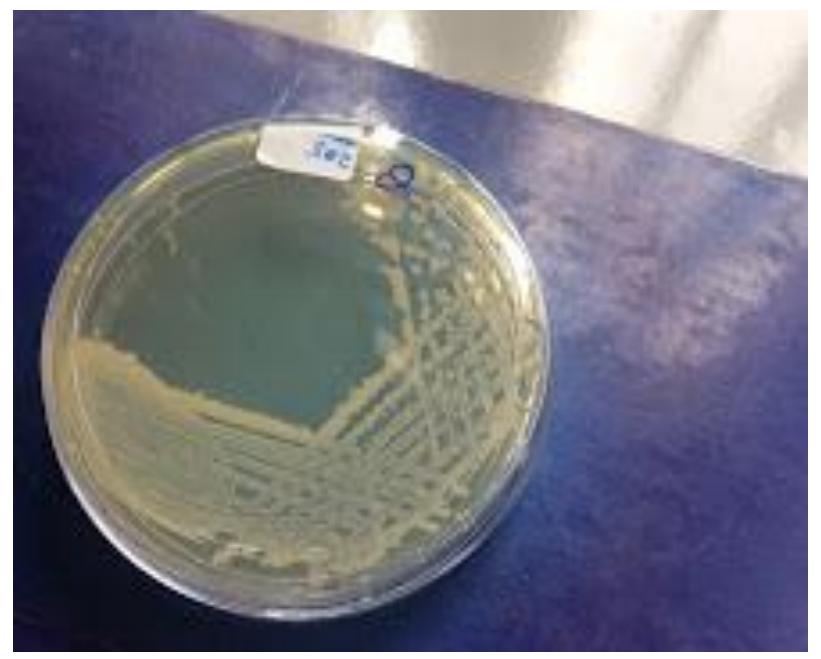

Fig.3 Agarose gel electrophoresis showing 159bpamplicon of 16srRNA gene of Clostridium chauvoei

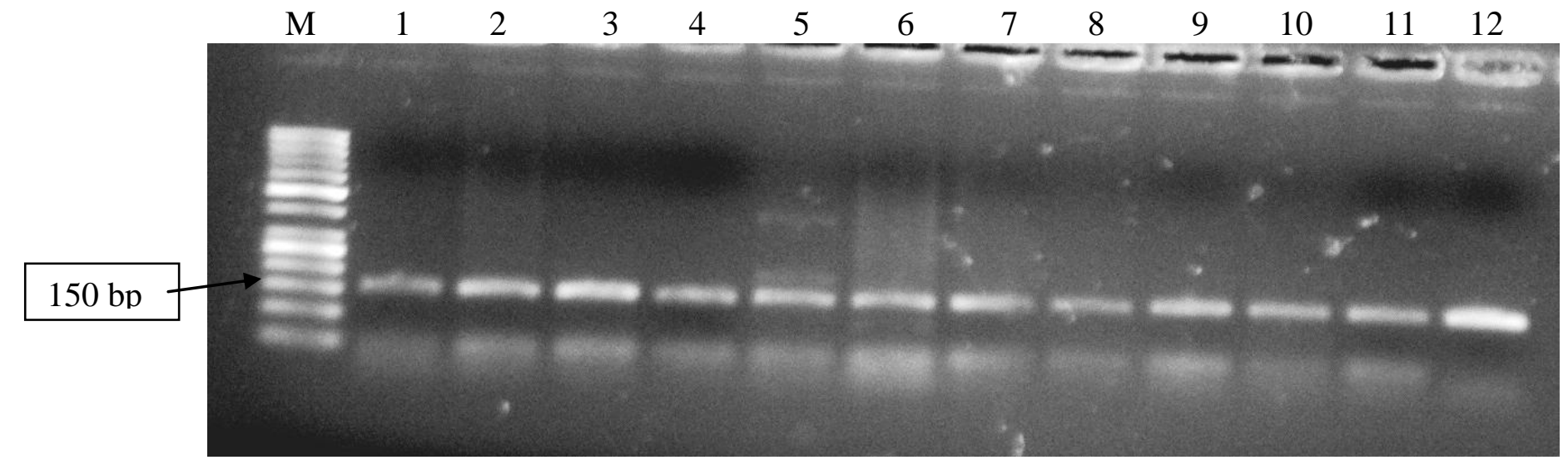

M: 50 bp ladder, L 1-11: Positive sample, L 12: Positive Control 
In the present study, $C$. chauvoei was isolated from $11.16 \%$ of total samples from sheep and goats. From healthy adult sheep and goats (without diarrhoea), the isolation rate was found to be $11.42 \%$ and $1.25 \%$ while the rate was $23.8 \%, 10 \%$ from healthy lambs and kids, respectively. In case of diarrhoeic animals, isolation rate was found to be $12.5 \%$ and $2.85 \%$ in case of adults, while it was $25 \%$ and $10 \%$ in young stock, respectively. The overall prevalence of the organisms in healthy animals was $9.43 \%$ and in diarrhoeic animal it was $13 \%$. No reports are available from Kashmir valley to compare the results. Bagge et al., (2009) screened 114bovine faecal samples in which one sample was positive. Recently, Idrees et al., (2014) isolated $C$. Chauvoei from tissue swabs and samples from infected muscles of cattle. $140 / 750(72.9 \%)$ suspected tissue swabs and $41 / 50(82 \%)$ muscle samples were found to be positive. Corroborating findings have also been reported by the Miyashiro et al., (2007), the author detected $C$. chauvoei by means of polymerase chain reaction from liver, muscle and metatarsian bone marrow samples of infected calves. Balakrishnan et al., (2013) also isolated $C$. chauvoe $i$ from muscle pieces of a cow which was suffering from black quarter in Tamil Nadu. Similar results have also been reported by Pires et al., (2012).

This is the first report on isolation of $C$. chauvoei from Kashmir valley, the rate of isolation of C. Chauvoei is more from sheep than goat. Isolates of $C$. chauvoei were significantly more from lambs and kids than adult animals and PCR has been shown to be much more rapid and reliable for final identification of $C$. chauvoei.

\section{Acknowledgement}

The authors thankfully acknowledge the Indian Council of Agricultural Research, New Delhi for the facilities under the Niche Area of Excellence on Anaerobic Bacteria project entitled "Study of Clostridium perfringens and Dichelobacter nodosus (Anaerobic Bacteriology)" utilized for this study.

\section{References}

Abreu, C.C. and Uzal, F.A. 1984. Blackleg. In: Clostridilal Diseases of Animals. Uzal, F.A, Songer J.G., Prescott, J.F. and Popff, M.R. (eds), Wiley Blackwell.

Bagge, E., Lewerin, S.S. and Johansson, K.E. 2009.Detection and identification by PCR of Clostridium chauvoeiin clinical isolates, bovine faeces and substrate from biogas plant. Acta Veterinaria Scandinavica, 51:8.

Balakrishnan, G., Ravikumar, G., Roy, P. and Purushothaman, V. 2013. Isolation and identification of Clostridium chauvoei from cattle suffered from black quarter. Journal of Pure and Applied Microbiology, 7(3): 2447-2449.

Dangi, S.K., Singh, A.P., Dangi, S.S., Thomas, P., Gupta, S.K., Agarwal, R.K. and Viswas, K.N. 2014. Polymerase chain reaction amplification and cloning of immunogenic protein NAD dependent beta hydroxyl butyry Co A dehydrogenase gene of Clostridium chauvoei.Veterinary World, 7: 848-851.

Hatheway, C. L. 1990. Toxigenic Clostridia. Clinical Microbiology Review, 3:66-98.

Hirsh, D.C., Maclachlan, N.J. and Walker, R.L. 2004. Veterinary Microbiology, $2^{\text {nd }}$ Ed., Wiley-Blackwell, pp. 206.

Idrees, A., Chaudhary, Z., Younus, M. and. Ashraf, K. 2014. Isolation and molecular detection of Clostridium chauvoei alpha toxin gene from clinical cases of black quarterin cattle. The Journal of Animal and Plant Sciences 24(3):755-759.

Jousimies-Somer, H.R., Summanen, P., Baron, E.J., Citron, D., Strong, C., Wexler, H.M., Finegold, S.M. and 
Wadsworth, K.T.L. 2003.Wadsworth Anaerobic Bacteriology Manual, $6^{\text {th }}$ Ed. Belmont, Calif Star Publishing Company, pp. 320.

Miyashiro, S., Nassar, A.F.C., Souza, M.C.A.M., Carvalho., J.B. and Adegas., J.E.B. 2007. Identification of Clostridium chauvoei in clinical samples culture from black leg cases by means of PCR. Brazilian Journal of Microbiology38:491-493.

Nagano, N., Isomine S., Kato, H., Sasaki, Y., Takahashi, M., Sakaida K., Nagano, Y. and Arakawa, Y. 2008. Human fulminant gas gangrene caused by Clostridium chauvoei. Journal of Clinical Microbiology 46:1545-1547.

Pires PS, Ecco R, de Araujo MR, Silva ROS, Salvarani, FM Heneine LGD, Assis RA and Lobato FCF (2012).Comparative analysis of lesion caused by histotoxic clostridium species, Clinical Veterinary Microbiology. London, UK, Pp. 191208.
Quinn, P.J., M.A. Carter, B. Markey and G.R. Carter (2004). Clinical Veterinary Microbiology. 2Ed: Elsevier - Health Sciences Division. USA, pp: 191-208.

Radostitis, O.M., C.C. Gay, K.W. Hinchcliff and P.D. Constable (2006) Diseases associated with Clostridium species in Veterinary Medicine. $10^{\text {th }}$ ed. WB Saunders Company Ltd. London. pp: 828-830.

Uzal, F.A., Hugenholtz, P., Blackall, L.L., Petray, S. Moss, S., Assis, R.A. Miyakawa M.F. and Carloni, G. 2003. PCR detection of Clostridium chauvoei in pure cultures and in formalin-fixed, paraffin-embedded tissues. Veterinary Microbiology, 91: 239-248.

Weatherhead, J.E. and Tweardy, D.J. 2012. Lethal human neutropenic enterocolitis caused by Clostridium chauvoei in the United State: Tip of the iceberg? Journal of Infection 64: 225-227.

Willis, T. A. 1969. Clostridia of wound infection, Butterworths, London.

\section{How to cite this article:}

Beigh, Q., I. Hussain, S.A. Wani, S. Rasool, Q. Nyrah, Z.A. Kashoo, N. Nazir, A.H. Wani and Qureshi, S. 2017. Occurrence of Clostridium chauvoei in Sheep and Goats in Kashmir Valley. Int.J.Curr.Microbiol.App.Sci. 6(11): 3195-3201. doi: https://doi.org/10.20546/ijcmas.2017.611.374 